\title{
EFFECT OF GLUTATHIONE SUPPLEMENTATION TO SEMEN EXTENDER ON COCKEREL SPERM CHARACTERISTICS IN SEMEN STORED AT $5^{\circ} \mathrm{C}$ FOR DIFFERENT PERIODS
}

\author{
Sh. M. Shamiah ${ }^{1}$, Ragaa E. Abd El-Karim ${ }^{1}$, Sara F. Fouda ${ }^{2}$, Abeir A.M. Eshera ${ }^{1}$ and I.T. El- \\ Ratel $^{3}$
}

1- Animal Production Research Institute, Agricultural Research Center, Giza, Egypt, 2- Department of Poultry Production, Faculty of Agriculture, Mansoura University, Masoura, Egypt, 3- Department of Poultry Production, Faculty of Agriculture, Damietta University, Damietta, Egypt, Corresponding Author: ibrahim.talat81@yahoo.com

\section{SUMMARY}

The present study was conducted to evaluate the effect of glutathione (GSH) supplementation at levels of 0 , 0.2, 0.4 and $0.6 \mathrm{mM}$ to diluted semen stored for $0,24,48$ and $72 \mathrm{~h}$ at $5^{\circ} \mathrm{C}$ on sperm characteristics and fertility rate (FR) of Inshas chickens. Effect of interaction between GSH level and storage period was not significant. Results revealed that progressive sperm motility (PSM), sperm livability (SL), sperm with curled tail (CT), sperm abnormality (SA) and acrosomal damage (AD) traits were improved by adding GSH to semen extender at all levels compared with no extender (control group). Semen diluted with $0.2 \mathrm{mM} \mathrm{GSH}$ showed the best results and semen without GSH supplementation (control) showed the poorest quality traits. Storage period had deleterious effect on all semen characteristics of cockerel spermatozoa. Percentages of PSM, SL and CT decreased, while those of $S A$ and $A D$ were increased by increasing storage period. The FR was higher for semen supplemented with $0.2 \mathrm{mM} \mathrm{GSH} \mathrm{(74.5 \% )} \mathrm{than} \mathrm{those} \mathrm{with} 0.6 \mathrm{mM} \mathrm{GSH}$ or free semen (59.9 and $59.2 \%$, respectively). However, FR of semen extended supplemented with $0.4 \mathrm{mM}$ GSH did not differ significantly when compared with other GSH levels, nor the control ones. The FR showed gradual reduction by increasing storage time, being the highest at $0 \mathrm{~h}$ and the lowest in semen stored for $72 \mathrm{~h}$. The FR was almost higher for semen supplemented with $0.2 \mathrm{mM} \mathrm{GSH}$ and stored at each period compared with other semen treatments.

In conclusion, supplementation of GSH at a level of $0.2 \mathrm{mM}$ to extender of cockerel semen stored at $5^{\circ} \mathrm{C}$ for up to $72 \mathrm{~h}$ is an appropriate level to improve semen characteristics and fertility rates of Inshas chicken spermatozoa.

\section{Keywords: Chicken, semen, antioxidant, preservation, sperm characteristics}

\section{INTRODUCTION}

Lipids as major compound in semen, particularly in sperm membrane, contribute also in sperm metabolism and their capacitatation and fertilizing ability of female gamete. This relationship was indicated in birds (Ansah and Buckland, 1982). In mammalian spermatozoa, adversely effects of lipid peroxidation (LPO) was reported in terms of losing fluidity of membrane, reducing function of acrosome, chromatin damage, and decreasing oocyte fusion by sperm (Long and Kramer, 2003). In mammals, membrane of spermatozoa has a high content of unsaturated fatty acids and sperm cells lack a significant cytoplasmic component containing antioxidants. Therefore, they are susceptible to LPO by $\mathrm{O}_{2}$ and $\mathrm{H}_{2} \mathrm{O}_{2}$ (Storey, 1997). Increasing the LPO in sperm cell membrane, as a result of exposing to reactive oxygen species (ROS), causes breakdown of membrane, increasing abnormality as well as decreasing motility of spermatozoa. Finally, decreasing capacity of sperm cells to penetrate oocyte (Wang et al., 1997 and Potts et al., 1999).

Membrane of avian spermatozoa is rich in polyunsaturated fatty acid (PUFAs) and can easily undergo LPO in the presence of ROS (Thananurak et al., 2015). During in vitro storage, avian semen tended to produce high LPO concentrations, resulting in a partial or complete losing the fertilizing capacity (Wishart, 1984). After in vitro storage, a direct relationship was observed between compromised function of poultry sperm and LPO (Cecil and Bakst, 1993). Deleterious effects of LPO on sperm cells in poultry lead to morphological defects, low motility, and decreasing fertilizing ability (Long and Kramer, 2003). In sheep, a defense mechanism against LPO, which plays a important role in maintaining sperm function included many types of antioxidants (catalase, glutathione, GSH; glutathione peroxidase, GPx; superoxid dismutase, SOD) as reported by Bucak et al. (2008).

In chicken breeders, sperm enrichment in n-3 or n-6 PUFAs for improving sperm production and fertilizing ability by different oil sources have been reported by Cerolini et al. (2006). In bovine, the oil supplementation may increase LPO, which may affect sperm function. Also, different processing procedures or semen preservation (at cool or room temperature), and exposing spermatozoa used in artificial insemination to oxygen and visible light radiation could lead to formation of ROS, and negatively affect motility and genomic integrity of 
spermatozoa (Bilodeau et al., 2001). To maintain sperm livability and motility, adding different types of antioxidants is vital under previous conditions (Bilodeau et al., 2001; Foote et al., 2002 and ElSherbieny et al., 2006).

The aim of the current study was to determine the effects of addition of reduced glutathione at levels of $0,0.2,0.4$ and $0.6 \mathrm{mM}$ to the extender of cockerel semen stored for $0,24,48$ and $72 \mathrm{~h}$ at $5^{\circ} \mathrm{C}$, on sperm characteristics and fertility of Inshas strain.

\section{MATERIALS AND METHODS}

The current study was carried out at Sakha Experimental Research Station, belonging to the Animal Production Research Institute, Agricultural Research Center, Ministry of Agriculture.

\section{Experimental chickens:}

Ten mature cockerels of local breed (Inshas strain), 9-10 months of age and $2.30-2.53 \mathrm{~kg}$ live body weight were used in this experiment.. All cocks were kept in an individual cages $(60 \times 50 \times 75 \mathrm{~cm})$, provided with laying mash diet containing $15.5 \%$ crude protein and $2700 \mathrm{kcl} \mathrm{ME} \mathrm{per} \mathrm{kg}$ diet. Water was available all daytime.

\section{Semen collection:}

Semen was collected in the morning from each cockerel once weekly by an abdominal massage method according to Lake and Stewart (1978) for five consecutive weeks as a semen collection period. Care was taken to avoid any contamination of semen with cloacae products and yellow and abnormal ejaculates were systematically discarded.

Only ejaculates with mass motility $\geq 70 \%$ on the day of collection were pooled on each collection day. Semen was evaluated for sperm cell concentration using a Neubauer hemacytometer, then semen was extended by the modified Beltsville Poultry Semen Extender (mBPSE) at a rate of 1 semen: 2 extender and divided into four parts; the $1^{\text {st }}$ part was extended with control extender without any supplementation (T1). However, the $2^{\text {nd }}, 3^{\text {rd }}$ and $4^{\text {th }}$ parts were supplemented with 0.2 (T2), 0.4 (T3) and 0.6 (T4) $\mathrm{mM}$ GSH $\left(\mathrm{C}_{10} \mathrm{H}_{17} \mathrm{~N}_{3} \mathrm{O}_{6} \mathrm{~S}\right)$, respectively, (S.d fineChem. Limited, India).

Semen extender supplemented with different $\mathrm{GSH}$ levels was stored in refrigerator at $5^{\circ} \mathrm{C}$ and evaluated after $0,24,48$ and $72 \mathrm{~h}$. Semen evaluation included PSM, SL, SA, acrosome status, and hypoosmotic swelling test (HOST) of spermatozoa.

\section{Semen evaluation:}

The PSM was assessed according to Tabatabaei et al. (2009), while SL was determined by eosin and nigrosin stain as described by Lukaszewicz et al. (2008). The SA was determined during the examination of SL at a high power magnification $(400 \mathrm{x})$.

As an alternative to evaluate the percentage of acrosomal abnormalities, staining procedure for fixed samples have been developed to distinguish which spermatozoa have retained or lost the acrosome to obtain percentage of spermatozoa with damaged acrosome (Al-Daraj, 2001).

The HOST as described by Lagares et al. (2000) was assessed to evaluate sperm membrane integrity. HOST-solution consisted of fructose (1.25\%) and Na-citrate $(2.9 \%)$ in distilled water (three times) to give osmolality at a level of $300 \mathrm{mOsm} / \mathrm{l}$ using osmometer (Osmett A, Model 5002, Fisher Svientific, Pittsbury, PA, USA). To reach osmolarity of $50 \mathrm{mOsm} / \mathrm{l}$, distilled water was added using osmometer. About $0.1 \mathrm{ml}$ of diluted semen was added to $0.9 \mathrm{ml}$ of the HOST-solution on a glass tube and the mixture was examined at $37^{\circ} \mathrm{C}$ after $30 \mathrm{~min}$. Slides were stained by eosin-nigrosine stain and examined to determine number of sperm cells with curled tails using research microscope (x 400).

\section{Fertility trial:}

Artificial insemination was performed using syringes $(1.0 \mathrm{ml})$ for the deposition of the semen according to Sadanand et al. (2004) to assess fertility rate. Hens from the same local breed were divided into 16 groups ( 7 hens for each treatment), including semen supplemented with $4 \mathrm{GSH}$ level at 4 storage periods). Total of 256 eggs, 16 from each group were collected after 1 day post-insemination for a week, and incubated to evaluate the fertility rate (FR). Eggs were candled to identify the fertile eggs according to the method of Islam et al. (2002) as the following: $\mathrm{FR}=$ Fertilized eggs $/$ incubated eggs $\mathrm{x} 100$.

\section{Statistical analyses:}

Data obtained were statistically analyzed as a factorial design (4 GSH levels $\mathrm{x} 4$ storage periods) by using analysis of variance ANOVA (SAS, 2001). The significant differences were set at 0.05 probability level and tested using the Duncan's procedure (Duncan, 1955). Data of fertility rates were analyzed using Chi-square.

\section{RESULTS AND DISCUSSION}

\section{Interaction between GSH level and storage period:}

No interaction effect between GSH level and storage period was observed in all studied traits $(\mathrm{P}<0.05)$. It is of interest to note that the data numerically indicated that semen extended with GSH at levels of 0.4 or $0.6 \mathrm{Mm}$ had long storage period up to $24 \mathrm{~h}$ as compared with the control semen $(<24 \mathrm{~h})$. Moreover, semen supplemented with $0.2 \mathrm{mM} \mathrm{GSH}$ maintained all sperm characteristics studied for the longest storage period up to $48 \mathrm{~h}$. However, unaccepted values of all sperm characteristics were obtained after $72 \mathrm{~h}$ of storage in all types of semen.

In accordance with the present results, Wang et al. (1997) observed an increase in ROS production in human semen stored at $4{ }^{\circ} \mathrm{C}$ by increasing storage time. Hydrogen peroxide $\left(\mathrm{H}_{2} \mathrm{O}_{2}\right)$, as ROS has been shown to negatively affect sperm motility in mouse, human, bull, and rabbit (Alvarez and Storey, 1989). 
In vitro storage of turkey sperm cells markedly affect the endogenous metabolism of the fatty acids of the membrane phospholipids and induce membrane destabilization, which was association with the decrease in quality of semen (Douard et al., 2000). Under the condition of semen storage, supplementation of the extenders with different antioxidants can help to maintain motility and livability of spermatozoa (Bilodeau et al., 2001 and Foote et al., 2002).

\section{Effect of GSH level:}

Semen quality in terms of PSM, SL, CT, SA and AD were significantly $(\mathrm{P}<0.05)$ improved by adding GSH to semen extender at all levels as compared with free extender (control). Semen diluted with 0.2 $\mathrm{mM}$ GSH showed higher percentages of PSM, SL and $\mathrm{CT}$, and lower percentages of $\mathrm{SA}$ and $\mathrm{AD}$ as compared with other groups $(\mathrm{P}<0.05)$. Semen without GSH (control) showed the poorest quality (Table 1). These results clearly indicate that addition of GSH to semen extender at a level of $0.2 \mathrm{mM}$ had impact on all sperm characteristics studied, regardless storage period.

Table 1. Sperm characteristics of cockerel as affected by glutathione supplementation to semen extender stored at $5^{\circ} \mathrm{C}$

\begin{tabular}{cccccc}
$\begin{array}{c}\text { GSH } \\
(\mathbf{m M})\end{array}$ & $\begin{array}{c}\text { Progressive } \\
\text { motility (\%) }\end{array}$ & $\begin{array}{c}\text { Live sperm } \\
(\%)\end{array}$ & $\begin{array}{c}\text { Abnormal } \\
\text { sperm (\%) }\end{array}$ & $\begin{array}{c}\text { Acrosomal } \\
\text { damage (\%) }\end{array}$ & $\begin{array}{c}\text { Curled tail } \\
(\%)\end{array}$ \\
\hline 0.0 & $33.00^{\mathrm{d}}$ & $39.20^{\mathrm{c}}$ & $18.60^{\mathrm{a}}$ & $20.40^{\mathrm{a}}$ & $31.65^{\mathrm{b}}$ \\
0.2 & $44.50^{\mathrm{a}}$ & $54.00^{\mathrm{a}}$ & $14.80^{\mathrm{b}}$ & $16.35^{\mathrm{b}}$ & $42.00^{\mathrm{a}}$ \\
0.4 & $40.00^{\mathrm{b}}$ & $45.95^{\mathrm{b}}$ & $16.70^{\mathrm{ab}}$ & $17.50^{\mathrm{ab}}$ & $38.10^{\mathrm{ab}}$ \\
0.6 & $36.25^{\mathrm{c}}$ & $41.45^{\mathrm{bc}}$ & $17.75^{\mathrm{ab}}$ & $18.10^{\mathrm{ab}}$ & $36.15^{\mathrm{ab}}$ \\
\pm SEM & 0.848 & 0.881 & 0.558 & 0.462 & 0.849 \\
\hline a, b, c and d. & Means denoted within the same column with different superscripts are significantly different at P<0.05.
\end{tabular}

In the current study, increasing GSH level above $0.2 \mathrm{mM}$ improved most of semen quality traits. In addition, the best results was observed in semen supplementation of $0.2 \mathrm{mM} \mathrm{GSH}(\mathrm{P}<0.05)$. In the literature we did not find publications referring to the effects of glutathione supplementation to semen extender on cockerel spermatozoa. However, in bull semen, adding GSH (0.4, 0.8 and $1.2 \mathrm{Mm})$ showed the best improvement at a level of $0.4 \mathrm{mM}$, but increasing GSH level up to $1.2 \mathrm{mM}$ showed the lowest PSM and SL percentages as compared with those in the control semen store at $5^{\circ} \mathrm{C}$. This may suggest that the toxic effect of this concentration affected negatively bull semen traits (El-Sherbieny et al., 2006). The effect of addition of natural antioxidants into semen diluents on the preservability of buffalo semen was studied by Raina et al. (2002). They found that sperm motility was significantly $(\mathrm{P}<0.01) \quad$ affected by extender-antioxidant combination in semen stored at $4-7^{\circ} \mathrm{C}$.

There are several reports about positive effects of $\mathrm{GSH}$ on sperm function. Addition of 0.5 -1.0 mM of GSH to diluents is sufficiently effective to protect the plasma membranes and maintain the percentage of bovine spermatozoa motility stored at $5{ }^{\circ} \mathrm{C}$ (Triwulanningsih et al., 2008). Also, in buffalo, ElKon and Darwish (2011) indicating that addition of $0.50-1.00 \mathrm{mM}$ of GSH to semen diluent improved quality of liquid semen stored up to 120 hours in terms of reducing DNA damage and improving the fertility.

During semen storage, oxidative damage to sperm resulting from ROS produced by the semen components. This finding is possibly one of the main reasons for the reduction in sperm motility and fertility in ram (Bucak and Tekin, 2007) and in bull (El-Sherbieny et al., 2006).
It is worth noting that GSH $(0.1-1.0 \mathrm{mM})$ significantly inhibits ROS generation in chicken semen, but had no effect on post-thawed spermatozoa quality (Thananurak et al., 2015). Also, others found no effect of GSH at $5 \mathrm{mM}$ on progressive movement of post-thawed boars' sperm (Whitaker et al., 2008) and on human sperm motility over a $4 \mathrm{~h}$ period (Donnelly et al., 1999). Similarly, no significant effect on semen quality of boar was found after addition of GSH to the thawing medium (Gadea et al., 2005a).

In turkey, Long and Conn. (2012) found that additional of phosphatidylcholine as antioxidants to the semen reduced the harmful effects of lipid peroxidation during semen storage at $4^{\circ} \mathrm{C}$. Also, administration of vitamins $\mathrm{C}, \mathrm{E}$, catalase (Amini et al., 2015a, b) and oleic acid (Eslami et al., 2016) to the rooster semen decreased the levels of malondialdehyde in seminal plasma and post-thawed of sperm.

\section{Effect of storage period:}

Data shown in Table (2) indicate that storage period had deleterious effect on all characteristics of cockerel spermatozoa. Percentages of PSM, SL and CT significantly $(\mathrm{P}<0.05)$ decreased, while those of $\mathrm{SA}$ and $\mathrm{AD}$ significantly $(\mathrm{P}<0.05)$ increased by advancing storage period. These findings were reported in turkey spermatozoa in semen preserved at cool temperature for $24 \mathrm{~h}$ (Sexton, 1986) and even in frozen semen by liquid nitrogen (Douard et al., 2000). In rooster, supplementation of oleate to semen extender caused an improve in total antioxidant activity concentration of seminal plasma and spermatozoa stored at $4^{\circ} \mathrm{C}$ for at $24 \mathrm{~h}$ and $48 \mathrm{~h}$ compared with control group (Eslami et al., 2016). 
Table 2. Sperm characteristics of cockerel as affected by storage period at $5^{\circ} \mathrm{C}$

\begin{tabular}{cccccc}
\hline $\begin{array}{l}\text { Storage } \\
\text { period (h) }\end{array}$ & $\begin{array}{c}\text { Progressive } \\
\text { motility (\%) }\end{array}$ & $\begin{array}{c}\text { Live } \\
\text { sperm (\%) }\end{array}$ & $\begin{array}{c}\text { Abnormal } \\
\text { sperm (\%) }\end{array}$ & $\begin{array}{c}\text { Acrosomal } \\
\text { damage (\%) }\end{array}$ & $\begin{array}{c}\text { Curled } \\
\text { tail (\%) }\end{array}$ \\
\hline 0 & $68.75^{\mathrm{a}}$ & $75.95^{\mathrm{a}}$ & $9.70^{\mathrm{d}}$ & $10.55^{\mathrm{d}}$ & $67.25^{\mathrm{a}}$ \\
24 & $37.25^{\mathrm{b}}$ & $49.90^{\mathrm{b}}$ & $14.45^{\mathrm{c}}$ & $16.20^{\mathrm{c}}$ & $39.85^{\mathrm{b}}$ \\
48 & $29.75^{\mathrm{c}}$ & $35.10^{\mathrm{c}}$ & $17.95^{\mathrm{b}}$ & $1825^{\mathrm{b}}$ & $24.70^{\mathrm{c}}$ \\
72 & $18.00^{\mathrm{d}}$ & $19.65^{\mathrm{d}}$ & $25.75^{\mathrm{a}}$ & $27.35^{\mathrm{a}}$ & $16.10^{\mathrm{d}}$ \\
\pm SEM & 0.848 & 0.881 & 0.558 & 0.462 & 0.849 \\
\hline
\end{tabular}

a, b, c and d: Means denoted within the same column with different superscripts are significantly different at $\mathrm{P}<0.05$.

\section{Fertility rate:}

Results presented in Table (3) show that overall mean of fertility rate (FR) of eggs after performing the artificial insemination of hens was affected by GSH level and storage period $(\mathrm{P}<0.05)$. GSH supplementation significantly $(\mathrm{P}<0.05)$ increased FR. Semen supplemented with $0.2 \mathrm{mM}$ GSH (74.5\%) showed higher FR than those supplemented with 0.6 $\mathrm{mM}$ GSH or free semen (59.9 and 59.2\%, respectively). However, FR of semen extended with $0.4 \mathrm{mM}$ GSH did not differ significantly from other GSH levels or from the control semen. Also, FR showed gradual reduction by increasing storage time $(\mathrm{P}<0.05)$, being the highest at $0 \mathrm{~h}$ and the lowest in semen stored for $72 \mathrm{~h}$ (Table 3 ).

Moreover, FR was higher for semen supplemented with $0.2 \mathrm{mM} \mathrm{GSH}$ and stored at any period as compared with other semen treatments, being the highest for fresh semen $(0 \mathrm{~h})$ with $0.2 \mathrm{mM}$ GSH (93.6\%, Table 3). Such results of different types of semen indicate FR of about $57 \%$ for semen stored for $72 \mathrm{~h}$ in semen extended with $0.2 \mathrm{mM} \mathrm{GSH}$. The GSH treatment and increasing storage time of chicken semen reduce the motility and may cause disruption in the membrane integrity of spermatozoa.

Table 3. Fertility rate (\%) of eggs of hens inseminated by semen supplemented with different GSH levels and stored at various periods as affected by storage period

\begin{tabular}{cccccc}
\hline $\begin{array}{c}\text { GSH } \\
\text { level } \\
(\mathbf{m M})\end{array}$ & $\mathbf{0}$ & $\mathbf{2 4}$ & $\mathbf{4 8}$ & $\mathbf{7 2}$ & $\begin{array}{c}\text { Storage period (h) } \\
\text { mean }\end{array}$ \\
\cline { 2 - 6 } & & & & & \\
\hline 0.0 & 90.9 & 61.6 & 50.3 & 33.9 & $59.2^{\mathrm{b}}$ \\
0.2 & 93.6 & 82.2 & 64.7 & 57.3 & $74.5^{\mathrm{a}}$ \\
0.4 & 91.8 & 71.5 & 54.6 & 55.6 & $68.4^{\mathrm{ab}}$ \\
0.6 & 91.1 & 53.9 & 52.8 & 41.91 & $59.9^{\mathrm{b}}$ \\
$\begin{array}{c}\text { Overall } \\
\text { mean }\end{array}$ & $91.9^{\mathrm{a}}$ & $67.3^{\mathrm{b}}$ & $55.6^{\mathrm{c}}$ & $47.2^{\mathrm{d}}$ & - \\
\hline a, b, c and $\mathrm{d}$ & Means denoted within the same row or
\end{tabular}
column with different superscripts are significantly different at $\mathrm{P}<0.05$.

Fertility rates were analyzed by Chi-square student test.

It is generally assumed that these changes are detrimental and are associated with a loss of fertilizing capacity. No available information in the literature regarding the influence of $\mathrm{GSH}$ supplementation to cockerel semen stored at cool temperature on fertility rates. However, in general,
FR is lower for stored than of fresh semen, after cervical insemination of rams (Maxwell and Watson, 1996). Mowever, addition of GSH has been shown to help to maintain sperm motility and improving sperm in vitro oocyte penetration ability (Gadea et al., 2005 b \& 2011). In agreement with the obtained results, Amina (2002) reported that increasing storage time of diluted semen from local chicken breed for $0,24,48$ and $72 \mathrm{~h}$ significantly $(\mathrm{P}<0.01)$ decreased FR by 5.12, 9.55 and $12.53 \%$, respectively. In broiler breeder, supplementation of canthaxanthin or biotin in diets (Rosa et al., 2012 and Daryabari et $a l ., 2015)$, improved the FR.

\section{CONCLUSION}

Semen supplemented with GSH was characterized by moderate resistance morphological defects, increases motility and livability of spermatozoa in preserved semen as well as fertility rates. Supplementation of GSH at a level of $0.2 \mathrm{mM}$ to extender of cockerel semen stored at $5^{\circ} \mathrm{C}$ for up to $72 \mathrm{~h}$ is an appropriate level to improve the fertilizing ability of chicken spermatozoa.

\section{REFERENCES}

Al-Daraj, H.J., 2001. Effects of holding temperature and time on acrosomal abnormalities of fowl sperms. Indian J Anim Sci. 71: 32 - 34.

Amini, M.R., H. Kohram, A. Zare Shahaneh, M. Zhandi, H. Sharideh, and M.M. Nabi, 2015a. The effects of different levels of vitamin $\mathrm{E}$ and vitamin $\mathrm{C}$ in modified Beltsville extender on rooster post-thawed sperm quality. Cell Tissue Bank. 16:587-592.

Amini, M.R., H. Kohram, A. Zare Shahaneh, M. Zhandi, H. Sharideh and M.M. Nabi, 2015b.The effects of different levels of catalase and superoxide dismutase in modified Beltsville extender on rooster post-thawed sperm quality. Cryobiology. 70:226-232.

Alvarez, J.G. and B. T. Storey, 1989. Role of glutathione peroxidase in protecting mammalian spermatozoa from loss of motility caused by spontaneous lipid peroxidation. Gamete Res. 23:77-90.

El-Saadany Amina, Sh. 2002. Use antioxidants in storing local cockerels semen. Ph.D. Thesis, Alex. Univ., Egypt. 
Ansah, G.A. and R.B. Buckland, 1982. Genetic variation in fowl semen cholesterol and phospholipid levels and the relationships of these lipids with fertility of frozen-thawed and fresh semen, Poult. Sci. 61:623-637.

Bilodeau, J.F., S. Blanchette, M.A. Sirard, and C. Gagnon, 2001. Thiols prevent $\mathrm{H}_{2} \mathrm{O}_{2}$-mediated loss of sperm motility in cryopreserved bull semen. Theriogenology. 56:275-86.

Bucak, M.N. and N. Tekin, 2007. Protective effect of taurine, glutathione and trehalose on the liquid storage of ram semen. Small Ruminant Research. 73:103-108.

Bucak, M.N., A. Atessahin, and A. Yüce, 2008. Effect of anti-oxidants and oxidative stress parameters on ram semen after the freeze-thawing process. Small Rumin. Res. 75:128-134.

Cecil, H.C. and M.R. Bakst, 1993. In vitro lipid peroxidation of turkey spermatozoa. Poult. Sci. 72: 1370-1378.

Cerolini, S., L. Zaniboni, A. Maldjian, and T. Gliozzi, 2006. Effect of docosahexaenoic acid and $\alpha$-tocopherol enrichment in chicken sperm on semen quality, sperm lipid composition and susceptibility to peroxidation. Theriogenology. 66:877-886.

Daryabari, H., A. Akhlaghi, M. J. Zamiri, Z.A. Pirsaraei, G.R. Mianji, H. Deldar, and A. N. Eghbalian, 2015. Oral administration of supplementary biotin differentially influences the fertility rate and oviductal expression of avidin and avidin-related protein-2 in low- and highfertility broiler line hens Poult. Sci. 94:289-295.

Donnelly, E.T., N. McClure, and S.E.M. Lewis, 1999. Antioxidant supplementation in vitro does not improve human sperm motility. Fertil. Steril. 72: 484-495.

Douard, V., D. Hermier, and E. Blesbois, 2000. Changes in turkey semen lipids during liquid in vitro storage. Biol. Reprod. 63:1450-1456.

Duncan, B.D. 1955. Multiple range and multiple F test. Biometrics. 11:1-42.

Eslami, M., A. Ghaniei, and R. H. Mirzaei, 2016. Effect of the rooster semen enrichment with oleic acid on the quality of semen during chilled storage. Poultry Science. 95:1418-1424.

El-kon, I.I., and S.A. Darwish, 2011. Effect of glutathione (GSH) on microscopic parameters and DNA integrity in Egyptian buffalo semen during liquid and frozen storage. Journal of Reproduction and Infertility. 3: 32-40.

El-Sherbieny, M.A., M.H. El-Nenaey, E.M.E. ElSiefy, and A.E. Abdel-Khalek, 2006. Effect of reduced glutathione supplementation on motility, livability and abnormality of holstein spermatozoa in: 1. semen stored at room and cool temperature. J. Agric. Sci. Mansoura Univ. 4: $1961-1970$.

Foote, R. H., C.C. Brockett, and M. T. Kaproth, 2002. Motility and fertility of bull sperm in whole milk extender containing antioxidants. Anim. Prod. Sci. 71: 13-23.
Gadea J., D. Gumbao, S.C. Mata, and R. Romar, 2005a. Supplementation of the thawing media with reduced glutathione improves function and the in vitro fertilizing ability of boar spermatozoa after cryopreservation. Journal of Andrology. 6: 749-756.

Gadea, J., F. Garcia-Vazquez, C. Matas, J.C. Gardon, S. Canovas, and D. Gumbao, 2005 b. Cooling and freezing of boar spermatozoa: supplementation of the freezing media with reduced glutathione preserves sperm function. J. Androl. 26:396-404.

Gadea, J., M. Molla, E. Selles, M.A. Marco, F.A. Garcia-Vazquez, and J.C. Gardon, 2011. Reduced glutathione content in human sperm is decreased after cryopreservation: effect of addition of reduced glutathione to the freezing and thawing extenders. Cryobiology. 62: 40-46.

Islam, M. S., M. A. R. Howlider, F. Kabir, and J.V Alam, 2002. Comparative assessment of fertility and hatchability of Barred Plymouth Rock, White Leghorn, Rhode Island Red and White Rock Hen. International J. Poult. Sci. 4: 85-90.

Lagares, M.A., R. Petzoldt, H. Sieme, and E. Klug, 2000. Assessing equine sperm-membrane integrity. Andrologia, 32:163-167.

Lake, P.E. and J.M. Stewart, 1978. Artificial insemination in poultry. Bulletin 213. London, UK, Ministry of Agriculture, Fish, and Food. Her Majesty's Stationary Office.

Long, J. A. and T. L. Conn, 2012. Use of phosphatidylcholine to improve the function of turkey semen stored at $4^{\circ} \mathrm{C}$ for 24 hours. Poult. Sci. 91:1990-1996.

Long, J.A. and M. Kramer, 2003. Effect of vitamin E on lipid peroxidation and fertility after artificial insemination with liquid-stored Turkey semen, Poult. Sci. 82:1802-1807.

Lukaszewicz, E., A. Jersey, A. Partyka, and A. Siudzinska, 2008. Efficacy of evaluation of rooster sperm morphology using different staining methods. Res. Vet. Sci. 85: 583-588.

Maxwell W. M. C. and P.F. Watson, 1996. Protective effect of taurine, glutathione and trehalose on the liquid storage of ram semen. Animal Reproduction Science.1:55-65.

Meister, A. 1983. Selective modification of glutathione metabolism. Science, 230: $472-477$.

Potts, R.J., T.M. Jefferies, and L.J. Notarianni, 1999. Antioxidant capacity of the epididymis. Hum Reprod 14:2513-2516.

Raina, V. S., A. R. Gupta, and S. Kiran, 2002. Effect of antification on preserability of buffalo semen. Asian-Australas J Anim Sci. 1: 16 -18.

Rosa, A. P., A. Scher, J. O. B. Sorbara, L. S. Boemo, J. Forgiarini, and A. Londero, 2012. Effects of canthaxanthin on the productive and reproductive performance of broiler breeders. Poult. Sci. 91:660-666.

Sadanand, D., G.U. Sontakke, S. Vedantam, D. Sanjiva, and S.S. Kholkute, 2004. Semen characteristics, cryopreservation and successful 
artificial insemination in the Blue rock pigeon (Columba livia). Theriogenology, 62: 139-153.

SAS, Institute. 2001. SAS User's Guide: Statistics version 6.12 ed. SAS Institute, Inc., Cary, NC., USA.

Sexton, T.J. 1986. Relationship of number of the number of spermatozoa inseminated to fertility of turkey semen stored $6 \mathrm{~h}$ at $5{ }^{\circ} \mathrm{C}$. British Poult. Sci. 27: 237- 246

Storey, B.T. 1997. Biochemistry of the induction and prevention of lipoperoxidative damage in human spermatozoa. Mol. Hum. Reprod. 3: 203 - 214.

Tabatabaei, S., R.A. Batavani, and A.R. Talebi, 2009. Comparison of semen quality in indigenous and Ross broiler breeder roosters. J Animal Vet Adv. 8:90-93.

Thananurak, P., C. Sittikasamkit, T. Vongpralub, and K. Sakwiwatkul, 2015. Effects of addition of reduced glutathione to thawing media on motility parameters, lipid peroxidation and fertility rate in frozen-thawed chicken spermatozoa. Khon Kaen AGR. J. 43 SUPPL. 2: 98-102.
Triwulanningsih, E., P. Situmorang, T. Sugiarti, R.G. Sianturi, and D.A. Kusumaningrum, 2008. The effect of glutathione addition in sperm diluents on the quality of bovine chilled semen. Indonesian Journal of Agriculture. 1:64-69.

Wang, Y., R.K. Sharma, and A. Agarwal, 1997. Effect of cryopreservation and sperm concentration on lipid peroxidation in human semen. Urology. 50:409-413.

Whitaker, B.D., B. Carle, T. Mukai, A. Simpson, L. $\mathrm{Vu}$, J.W. Knight, 2008. Effect of exogenous glutathione supplementation on motility, viability, and DNA integrity of frozen-thawed boar semen. Anim. Reprod. 5:127-131.

Wishart, G. J. 1984. Effects of lipid peroxide formation in fowl semen on sperm motility, ATP content and fertilizing ability. J. Reprod. Fert. $71: 113-118$

$$
\begin{aligned}
& \text { تأثير الجلوتاثيون المضاف المى مخفف السائل المنوى على خصائص السائل المنوى للايوك المحلية والمخزن على درجة } \\
& \text { حرارة هْم لفترات تخزين مختلفة المفنئة } \\
& \text { شريف مغاورى شامية '، رجاء السيد عبد الكريم' ، سارة فكرى فودة' ،عبير احمد عشرة ' و ابراهيم طلعت الرطلّ } \\
& 1 \text { ـ معهل بحوث الإنتاج الحبيوانسي، مركز البحوث الزراعية، ب ـ قسم انتاج الدواجن ، كلية الزراعة، جامعة المنصورة ، بـ ـ قسم انتاج الدواجن ، } \\
& \text { كلية النزراعة، جامعة دمباط }
\end{aligned}
$$

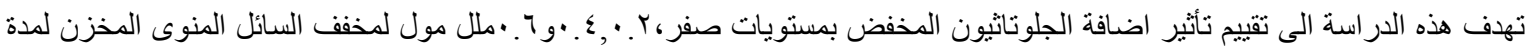

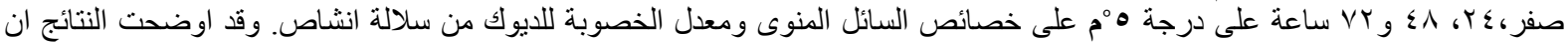

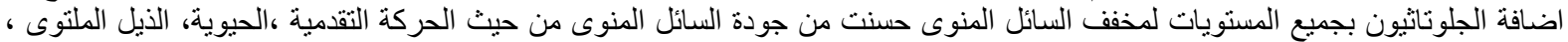

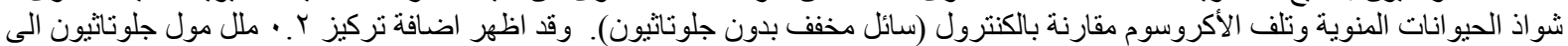

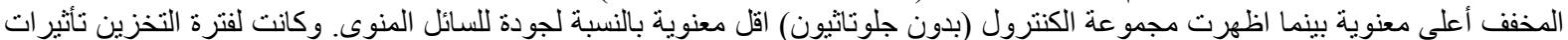

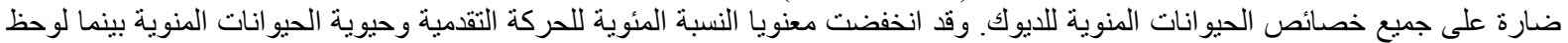

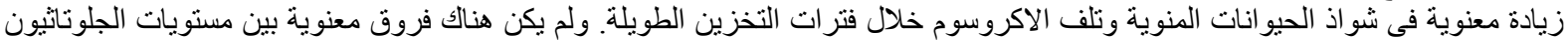

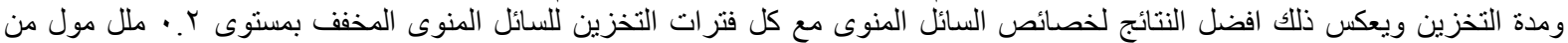

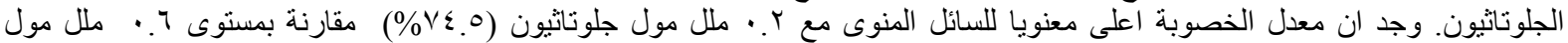

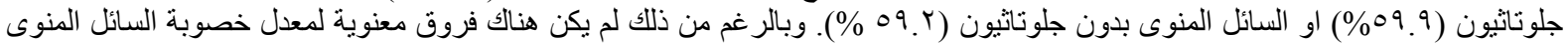

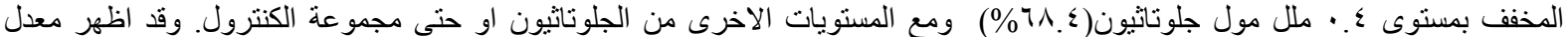

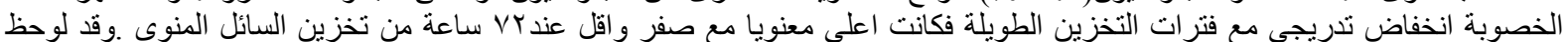

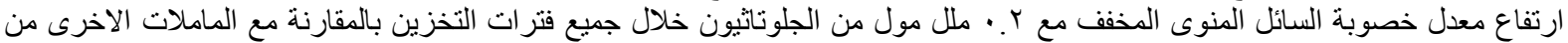

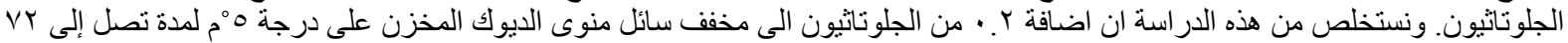
ساعة هو المستوى المناسب لتحسين المقدرة الاخصابية للحيو انات المنوية للانيون التيوك من سلالة أنشاص المحلية. 